\title{
Mycosphere Essay 10: Properties and characteristics of microbial xylanases
}

\section{Álvarez-Cervantes $\mathbf{J}^{2}$, Domínguez-Hernández $\mathbf{E M}^{3}$, Mercado-Flores $\mathbf{Y}^{2}$, O'Donovan $\mathrm{A}^{4}$ and Díaz-Godínez $\mathrm{G}^{1}$}

\author{
${ }^{1}$ Laboratorio de Biotecnología del Centro de Investigación en Ciencias Biológicas, Universidad Autónoma de \\ Tlaxcala.Tlaxcala, México.diazgdo@hotmail.com. \\ ${ }^{2}$ Laboratorio de Aprovechamiento Integral de Recursos Bióticos. Universidad Politécnica de Pachuca. Zempoala, \\ Hidalgo,México.jorge_ac85@upp.edu.mx; yuridia_utsh@hotmail.com. \\ ${ }^{3}$ Instituto Tecnológico Superior del Oriente del Estado de Hidalgo. Apan, Hidalgo, México. ehernandez@itesa.edu.mx. \\ ${ }^{4}$ Molecular Glycobiotechnology Group, Department of Biochemistry, School of Natural Sciences, National University \\ of Ireland Galway, Galway, Ireland. toniodonovan@gmail.com.
}

Álvarez-Cervantes J, Domínguez-Hernández EM, Mercado-Flores Y, Díaz-Godínez G 2016 Mycosphere Essay 10: Properties and characteristics of microbial xylanases. Mycosphere 7(10), 1600-1619, Doi 10.5943/mycosphere/si/3b/12

\begin{abstract}
Xylanases are a group of enzymes that hydrolyze xylan which is a primary constituent of hemicellulose, the second most abundant polysaccharide in nature. These enzymes are endo- $\beta-1,4-$ xylanases, they include debranching enzymes such as xylosidases, glucoronidases, arabinofuranosidases and acetylxylan esterase. They are produced by algae, crustaceans, insects, bacteria, fungi and yeasts, with microbial sources being the most commercially important. There are multiple genes for its production, resulting in xylanases with different biochemical characteristics in terms of $\mathrm{pH}$ and temperature optimimum, $\mathrm{pI}$ and molecular weight. This review describes the importance of xylanases in the hydrolysis of xylan to obtain xylose and xylitol and their applications in pharmaceutical, paper and food industries.
\end{abstract}

Key words - enzymes - hemicellulose - microorganisms - xylan

\section{Introduction}

Xylanases are a group of enzymes which degrade xylan (linear polysaccharide $\beta-1,4-x y l a n$ ) present in hemicellulose. These enzymes play a major role in microorganisms which use plants as nutrimental sources. Xylanases are produced by bacteria, yeast, fungi, protozoans, marine algae, snails, crustaceans, insects and seeds among others (xylanases are not produced by mammals). Filamentous fungi are the principal commercial source of xylanases.

\section{Xylan}

Xylan is the second most abundant polysaccharide in nature after cellulose (Beg et al. 2001, Collins et al. 2005, Polizeli et al. 2005). It is part of the hemicellulose present in the amorphous matrix of the secondary cell wall of lignified tissue of woody plants, cereals and other plant material (Timell 1967, Motta et al. 2013). It can also be found in the matrix of primary cell walls during growth, as well as in seeds and bulbs, where they have a reserve function. In hardwoods 
(angiosperms), xylan represents $15-30 \%$ of the dry weight of the plant cell wall but is less abundant in the case of softwoods (gymnosperms), where the xylan content is only $7-12 \%$ of dry weight (Schulze 1891, Wong et al. 1988, King et al. 2011). Its function appears to be basically structural in maintaining the integrity of the cell wall together with other components; hemicellulose, cellulose, pectin and lignin. Furthermore, together with lignin, it helps to protect cellulose microfibrils against biodegradation (Wong et al. 1988, Cano \& Palet 2007, King et al. 2011, Sharma \& Kumar 2013).

Xylan is formed by a backbone of $\beta$-D-xylose molecules linked together by $\beta(1 \rightarrow 4)$ links, and in marine algae; $\beta(1 \rightarrow 3)$ links. The chain may have a different degree of polymerization, being higher for hardwoods (xylose residues 150-200) than softwoods (xylose residues 70-130) (Kulkarni et al. 1999, Yang et al. 2005, Yang et al. 2007). Normally, the chain of $\beta$-D-xylopyranoses has lateral branches differing in nature. Although in some terrestrial plants and algaea homoxylans are found, most often, the xylan is in the form of heteropolysaccharides. The number and nature of these side branches depends on the plant species and the type of tissue (Beg et al. 2001, Verma \& Satyanarayana 2012). Xylan can bind to cellulose and other xylan chains and hemicellulose by covalent and non-covalent bonds, hydrogen bonds and Van der Waals force, and to lignin by covalent bonds of either type with coumaric acid and ferulic acid esterified to arabinose residues (glucuronoarabinoxylan and arabinoxylans) and ester linkages with 4-O- methylglucuronic acid (glucuronoxylan and glucurono arabinoxylan). Chains of (glucurono)arabinoxylans and arabinoxylans can be linked together and with other hemicelluloses and lignin through the formation of diferulates (two ferulic acid residues linked by a covalent bond) (Markwalder \& Neukom 1976, Motta et al. 2013, Sharma \& Kumar 2013) (Fig. 1).

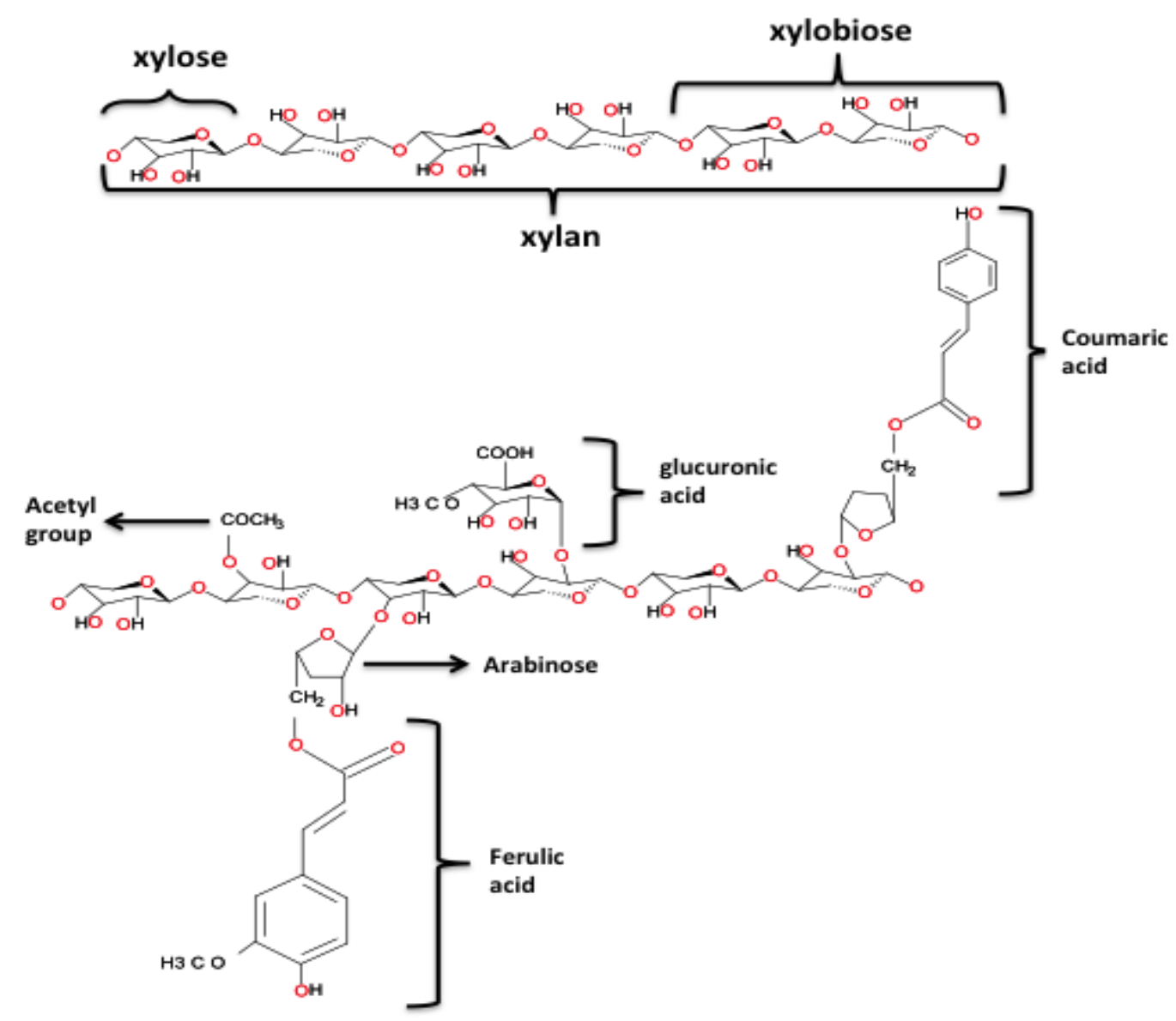

Fig. 1 - Structure of xylan. 


\section{Enzymatic hydrolysis of xylan}

Due to the heterogeneity and the complex chemical nature of xylan, complete breakdown requires a complex set of hydrolytic enzymes (Coughlan \& Hazlewood 1993, Kim et al. 2000, Beg et al. 2001). The ability to degrade xylan is widely distributed among saprophytic organisms, both bacteria and fungi as well as in the rumen microbiota. These microorganisms produce different types of enzymes to carry out the degradation of xylan (Biely 1997, Motta et al. 2013, Sharma \& Kumar 2013). Xylan degrading enzymes are classified into two main groups (Fig. 2): Depolymerization enzymes of the main xylose skeleton: endoxylanases ( $\beta$-1,4-D-xylan-xylan hydrolases) and $\beta$-xylosidases ( $\beta$-1,4-D-xylan-xylo hydrolases). Enzymes responsible for removing the side chains of xylan, are also called accessory or debranching enzymes: $\alpha$-Larabinofuranosidases, $\alpha$-D-glucuronidases, acetyl xylan esterases, ferulic esterases and p-coumaric esterases (esterase hydroxycinnamic). These enzymes act cooperatively to convert xylan into its constituent sugars (De Vries et al. 2000, Polizeli et al. 2005, Juturu \& Wu 2012).

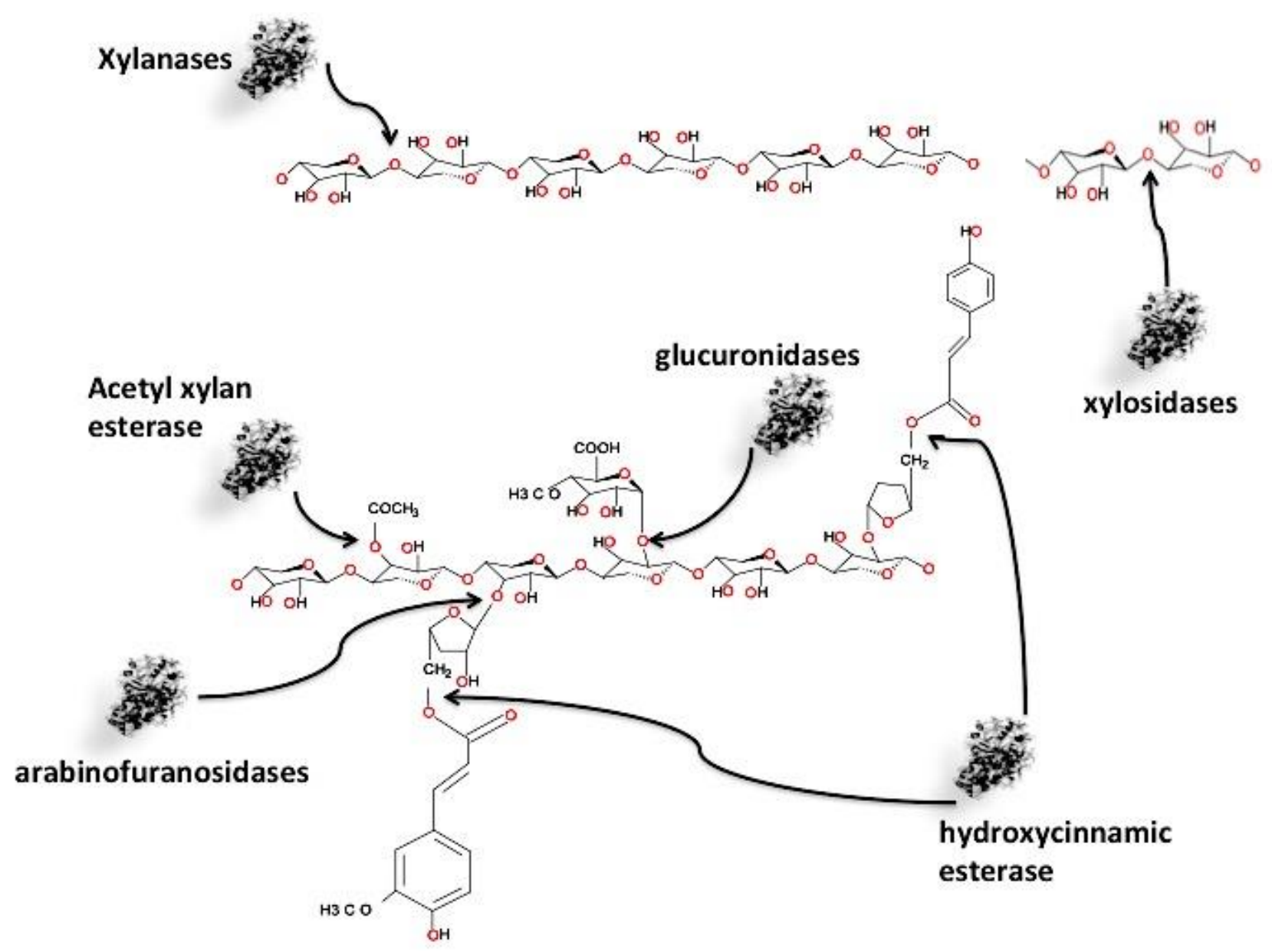

Fig. 2 - Enzymes necessary for degradation of xylan and sites of action.

Kulkarni et al. (1999) and Motta et al. (2013) mentioned that endoxylanases are the most important enzymes because they cleave glycosidic bonds releasing xylooligosaccharides. If the substrate has a high molecular weight, the enzyme does not penetrate the cell wall. Xylan hydrolysis plays an important role in regulating the biosynthesis of xylanases; fragments such as xylose, xylobiose and xylooligosaccharides released during depolymerization of xylan is due to the action of small amounts of constitutively produced enzyme. 


\section{Xylanases}

Xylanases are enzymes responsible for degradation of xylan, these are produced by algae, crustaceans, insects, yeasts, bacteria and fungi (Sunna \& Antranikian 1997, Beg et al. 2001, Subramaniyan \& Prema 2002, Howard et al. 2003, Polizeli et al. 2005). Hydrolysis of the xylan backbone is performed by the action of endo- $\beta(1 \rightarrow 4)$-xylanases (EC 3.2.1.8). This enzymes catalyze the random hydrolysis of xylan to xylooligosaccharides, while $\beta$-xylosidases act on nonreducing ends of xylooligosaccharides (Sapag et al. 2002, Anthony et al. 2003, Monti et al. 2003, Aro et al. 2005). Endoxylanases or xylanases are classified as glycosil-hydrolases (endo- $\beta-1,4-$ xylanase; EC 3.2.1.8). They can hydrolyze xylo-oligomers of different degrees of polymerization (being more active at higher degrees of polymerization) but cannot hydrolyze xylobiose, allowing them to be clearly distinguished from $\beta$-xylosidases. In xylanolytic microorganisms, there are a multiplicity of xylanases (result of several genes and/or post-transcriptional and post-translational processing), which differ in their specificity regarding xylan (Wong et al. 1988). Diversity of xylanases is due to their high specificity, and many of these enzymes can only act on regions that are not substituted, while others require a particular type of branching adjacent to the cleavage site (Coughlan \& Hazlewood 1993, Kulkarni et al. 1999, Polizeli et al. 2005, Juturu \& Wu 2012).

Other enzymes operate synergistically, acting on oligomers or dimers, resulting in the complete degradation of the polymer. Generally, polysaccharide degrading enzymes are subject to regulation mechanism synthesis. They are not constitutively produced, rather, their synthesis is induced by the appropriate substrate and is repressed readily by assimilated sugars, in particular glucose. The most efficient inducers are the polymer-substrate for which the enzymes will be synthesized, however, due to their high molecular weight, these complex substrates cannot enter microbial cells and exert their effect (Kumar et al. 2008). So, the xylanases have to be secreted into the extracellular medium, usually by type II systems ("Sec pathway") (Tjalsma et al. 2004). However, in some rumen bacteria and Cellvibrio mixtus, xylanases have been described which are not secreted into the extracellular space, but localized in the periplasmic space (Fontes et al. 2000). Probably, the function of these periplasmic enzymes is not degradation of xylan, but small xylooligosaccharides which can pass through the outer membrane, while they are protected from the action of extracellular proteases (Bayer et al. 2004).

In order for a microorganism to consume the xylan component of the medium, small basal expression of xylanases is necessary to release sufficient amounts of xylose which then acts to induce the expression of xylanases (Kulkarni et al. 1999, Stülke \& Hillen 2000). Furthermore, in most microorganisms, xylanase expression is subject to catabolite repression, through the action of the repressor CreA (Cho \& Choi 1999, De Vries et al. 1999), CcpA equivalent in species of the genus Bacillus (Stülke \& Hillen 2000). This allows the use of readily assimilable carbon sources (such as glucose and xylose) when they are available in the broth. Thus, xylose plays a dual role as a regulator of xylanase expression depending on its concentration; at low concentrations it acts as an inducer since a weak repression is exerted through the CreA system; but at high concentrations, xylose acts to repress expression through the CreA system (De Vries et al. 1999).

\section{Xylanase production}

The industrial production of xylanases depends on the composition of the culture medium, the presence of inducer and the producer microorganism. Filamentous fungi produce more xylanases than yeast and bacteria. Aspergillus and Trichoderma species are used for the production of xylanases with xylan as substrate; these strains produce both xylanases and cellulases, when cellulose is used as substrate. Fungi generally require acid $\mathrm{pH}$ but actinomycetes and bacteria require a neutral or alkaline $\mathrm{pH}$ to produce xylanases. The most important microorganisms include Aspergillus, Trichoderma, Streptomyces, Phanerochaetes, Chytridiomycetes, Ruminococcus, Fibrobacteres, Clostridium and Bacillus (Biely 1993, Velkova et al. 2007, Goswami \& Pathak 2013).

However, currently scientists are looking for new sources of xylanase, using induction techniques or improvement of strains by mutation, enabling the excretion of large amounts of 
enzyme. Furthermore, studies are underway to investigate the effects of changing nutritional and physiological conditions for microorganisms by varying the carbon and nitrogen sources supplied as well as the physical and chemical conditions of the culture. For example, agitation is used to homogenize the medium in bioreactors, but the force can fractionate the biomass and disrupt hyphal growth, leading to low productivity of xylanase (Motta et al. 2013). Most xylanases are produced by submerged fermentation (SMF) representing $90 \%$ of total sales, however it has been observed that enzymatic productivity through solid-state fermentation (SSF) is typically much higher than in SMF. Currently, there is interest in the use of SSF techniques for producing a variety of enzymes, where the xylanases of fungi are included, mainly due to economic and process engineering advantages such as reduced risk of contamination and enzyme stability. The substrate imitates the natural habitat of the fungi and high specific activities are obtained and byproduct enriched with protein is generated. SSF conditions are suitable for growth of filamentous fungi, since these organisms are able to grow with relatively low water supplies, unlike most bacteria and yeasts which do not proliferate under these culture conditions. Overall SMF is a suitable method when purified enzymes are required. In SSF systems, producing complex sets of enzymes is possible due to the use of complex substrates. The choice of substrate is of great importance in the selection of the fermentation process and thus effects the successful production of xylanases. Purified xylan, when used as substrate is usually excellent because of its low molecular weight which helps the induction of xylanases. However, for large-scale processes other alternatives should be considered due to the high cost of purified substrates. Therefore, lignocellulosic residues are an excellent choice for use as substrates, such as barley straw, corn cob, straw or wheat bran (Viikari et al. 1994, Beg et al. 2001, Bajpaj 2004, Sigoillot et al. 2005, Collins et al. 2005, Polizeli et al. 2005, Nair et al. 2010, Motta et al. 2013, Sharma \& Kumar 2013).

\section{Fungal xylanases}

Filamentous fungi are particularly interesting for the production of xylanases as they secrete enzymes into the medium and their activity levels are higher than those of yeast and bacteria. Fungi also produce other auxiliary enzymes necessary for degradation of xylan. The genera Trichoderma, Aspergillus, Fusarium are major producers of xylanase. The basidiomycete group of fungi have demonstrated the ability to produce extracellular xylanases acting on a wide range of hemicellulosic materials, producing metabolites of interest for the pharmaceutical, cosmetic and food industries. For example Phanerochaete chrysosporium, Trametes versicolor and Cuninghamella subvermispora present enzymes with xylanolytic activity when grown on plant cell wall material or wood chips. Most fungi produce xylanases that tolerate temperatures up to $50^{\circ} \mathrm{C}$ (Polizeli et al. 2005, Motta et al. 2013). Recent studies have described the production of xylanases by solid and liquid fermentation systems by the pathogenic fungi Sporisorium reilianum and Stenocarpella maydis. These enzymes could be related to the life cycle of the fungus and the host during colonization (Álvarez-Cervantes et al. 2013, Hernández-Domínguez et al. 2014).

\section{Bacterial xylanases}

Bacteria such as Bacillus and Streptomyces have been reported to produce xylanases. Xylanases of bacteria in recent years have drawn attention because of their high thermal stability and alkalinity properties. The optimum $\mathrm{pH}$ of bacterial xylanases is higher than the $\mathrm{pH}$ optimum of fungal xylanases. Bacillus SSP-34 produced higher levels of $\beta-1,4$ endoxylanase $(506 \mathrm{U} / \mathrm{mL})$ under optimum nitrogen content. Furthermore, Bacillus circulans had xylanase activity of $400 \mathrm{U} / \mathrm{mL}$ (Subramaniyan \& Prema 2002, Motta et al. 2013, Sharma \& Kumar 2013).

\section{Classification and structure}

In general, xylanases of bacteria and fungi, are mainly monomeric and widely variable in their molecular weight and isoelectric point (pI). They are classified into two groups: xylanases of low molecular weight (less than $30 \mathrm{kDa}$ ) and alkaline $\mathrm{pI}$ and xylanases of high molecular weight (greater than $30 \mathrm{kDa}$ ) and acid pI. However, with increasing xylanases being characterized there are 
enzymes described with intermediate characteristics, which do not fit into any of these two groups (Wong et al. 1988, Juturu \& Wu 2012, Motta et al. 2013). Xylanases were also classified in the families of glycosyl hydrolases and were grouped into 35 families based on sequence comparison (Henrissat 1991) and analysis of regions of hydrophobicity (Henrissat \& Bairoch 1996). There are currently more than 100 families of glycosyl hydrolases (Coutinho \& Henrissat 1999), which are grouped into different clans or superfamilies (groups of families sharing a source of tertiary folding, conserved catalytic amino acids and similar catalytic mechanisms; facts that suggest a common evolutionary origin). Based on this classification, the xylanases are distributed in families 10 and 11 , which correspond to the $\mathrm{F}$ and $\mathrm{G}$ families. In the case of xylanases from family 10 , most have carbohydrate binding domains linked to the catalytic domain by flexible linkers. It is possible, the presence of these flexible linkers has hindered crystallization and subsequently obtaining complete modular three-dimensional structures of xylanases of this family. Family 11 of glycosyl hydrolases belong to clan GH-C. Xylanases of this family have catalytic domains of 180-200 amino acids that fold into a $\beta$ sheet conformation curved on itself, known as $\beta$ jelly roll. These xylanases usually contain only the catalytic domain, although there are exceptions, as in the case of xylanase TfxA of Thermomonospora fusca bacterium, having a carbohydrate binding module linked to the catalytic domain (Biely et al. 1997, Kulkarni et al. 1999, Juturu \& Wu 2012, Motta et al. 2013, Sharma \& Kumar 2013).

The difference between these two families of xylanases is mainly seen at the sequence level and three dimensional structures. There are no significant differences in terms of their catalytic properties. However, structural differences have a decisive influence in some physicochemical characteristics of these enzymes. Thus, the three dimensional structure of the active center of xylanases from family 10 makes them less stringent with the substrate and more active on xylooligosaccharides with a low degree of polymerization than the xylanases of the family 11 (Biely et al. 1997, Leggio et al. 2000, Sabini et al. 2001, Juturu \& Wu 2012, Motta et al. 2013).

\section{Catalysis of xylanases}

Glycosyl hydrolases in their catalytic mechanism perform a simple displacement (producing inversion of anomeric configuration) or double displacement (retention of anomeric configuration) (Kulkarni et al. 1999, Rye \& Withers 2000, Yip \& Withers 2004). For xylanases of families 10 and 11 the mechanism used in the hydrolysis of the substrate is double displacement with retention of the anomeric configuration $(\beta \rightarrow \beta)$ (Fig. 3). There are 2 conserved glutamate residues involved in the active site, one of them acting as acid/base catalyst and the other as a nucleophilic residue (Davies \& Henrissat 1995, Biely et al. 1997, Kulkarni et al. 1999, Kolenova et al. 2006).

Once xylose is positioned between the two catalytic glutamic acids, one of them (the acid/base catalyst) performs an acid attack on the glycosidic bond protonating the oxygen, while the other glutamate makes a nucleophilic attack on the anomeric carbon of the link (Fig. 3A). The result of this first step is the release of one of the reaction products and the formation of an $\alpha$ glycosyl-enzyme intermediate. Then the acid/base glutamate acts as a base, "stealing" a proton to a water molecule, which enables it to attack the bond between the nucleophile glutamate and the anomeric carbon (Fig. 3B), resulting in hydrolysis and producing a product whose anomeric carbon returns to the same configuration as in the substrate $(\beta \rightarrow \beta)$, releasing the enzyme to start a new process of catalysis (Fig. 3C) (Davies \& Henrissat 1995, Biely et al. 1997, Kulkarni et al. 1999, Rye \& Withers 2000, Collins et al. 2005, Kolenova et al. 2006).

\section{Xylanase isoforms}

Extracellular xylanases exist in multiple forms. The synthesis of isozymes may be due to products of different genes, but may also be due to post-translational changes during proteolysis and glycosylation. These can be synthesized as a result of different physiological states, composition of culture medium, $\mathrm{pH}$, temperature and gene regulation. Notably, in slightly modified broths, several forms of the same enzyme are synthesized, and despite having similar catalytic properties they exhibit differences in their physicochemical characteristics. It follows that there are 


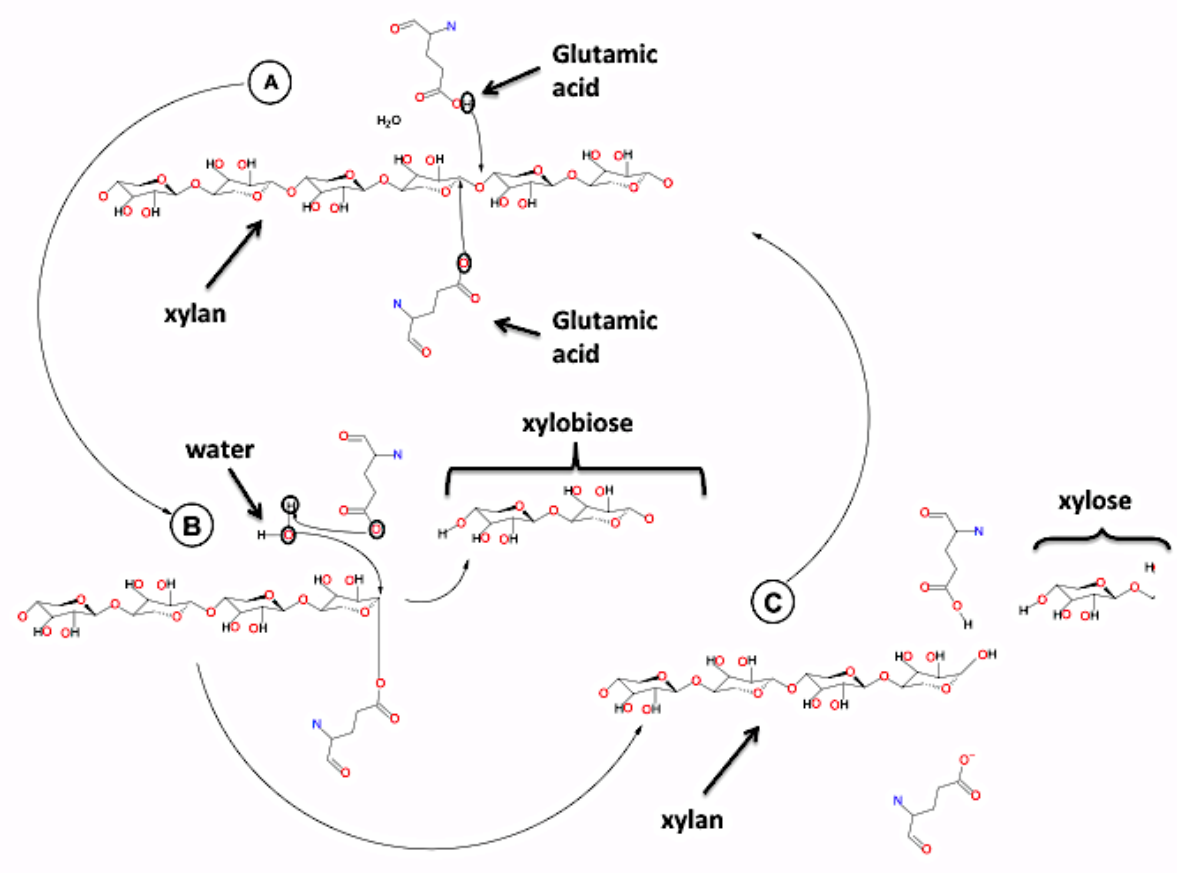

Fig. 3 - Catalytic mechanism of xylanases from families 10 and 11.

multiple forms that coexist at certain times but isozyme composition may also vary during microorganism growth. In nature, fungi grow in different environmental conditions and substrates, this may result in the production of different enzyme forms which are more appropriate to the new circumstances and allow them to degrade the polymer more efficiently (Sung et al. 1995, Segura et al. 1998, Kulkarni et al. 1999, Chavez et al. 2002, Polizeli et al. 2005).

\section{Properties of xylanases}

The properties of most xylanases have been elucidated by studies in bacteria, fungi and yeast (Table 1). Fungal xylanases are more thermostable than those produced by bacteria (Kulkarni et al. 1999, Polizeli et al. 2005, Harris \& Ramalingam 2010, Juturu \& Wu 2012, Motta et al. 2013).

\section{Synergy of xylanase complex}

One of the most important aspects for the degradation of xylan is the synergy of the different enzymes required to act on the substrate. Adding acetylxylanesterases permits release of acetic acid and therefore a less acetylated xylan, allowing greater accessibility for the hydrolysis of the polysaccharide by endoxylanases. Furthermore, acetylated fragments released by these enzymes, are the substrate for esterases. A complex hemicellulosic substrate is wheat bran, it contains high amounts of arabinoxylan, which cannot be degraded by endoxylanases, first $\alpha$ arabinofuranosidases should act to allow entry of the endoxylanases and thus improve the saccharification of arabinoxylan. Another important enzyme is $\beta$-xylosidase, which hydrolyzes xylooligosaccharides produced by endoxylanases, for total hydrolysis of xylan (Kulkarni et al. 1999, Polizeli et al. 2005, Motta et al. 2013, Sharma \& Kumar, 2013).

\section{Biochemical properties}

In Table 1, the biochemical characteristics of purified xylanases produced by fungi, bacteria and yeasts are shown. The molecular weight of these enzymes is between 15-145 kDa, while the optimal $\mathrm{pH}$ and temperature are between $4-6$ and $40-70{ }^{\circ} \mathrm{C}$, respectively. The isoelectric point for endoxylanases is between 3 and 10. These characteristics suggest that microorganisms have different strategies for the expression of xylanases in different environmental conditions, for the degradation of xylan (Polizeli et al. 2005, Harris \& Ramalingam 2010, Juturu \& Wu 2012, Motta et al. 2013, Goswami \& Pathak 2013). 
Table 1 Biochemical characteristics of xylanases of different organisms.

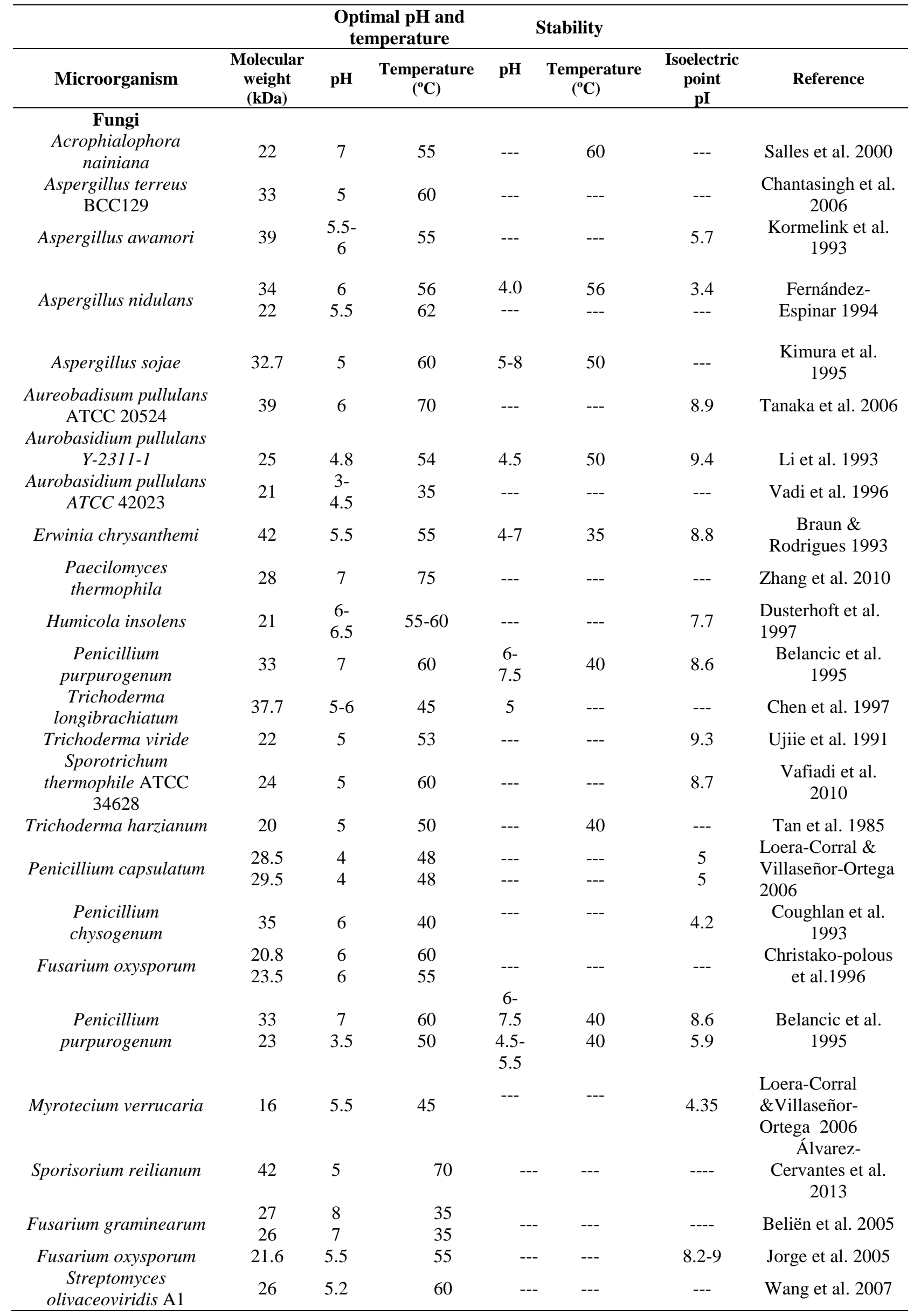




\begin{tabular}{|c|c|c|c|c|c|c|c|}
\hline Lentinula edodes & 29.5 & 4.5 & 50 & --- & --- & 4.6 & Lee et al. 2005 \\
\hline $\begin{array}{c}\text { Thermomises } \\
\text { lanuginosus DSM } 5826 \\
\text { Bacteria }\end{array}$ & 25.5 & 7 & $50-70$ & --- & --- & 4.1 & $\begin{array}{c}\text { Cesar and Mrsa, } \\
1996\end{array}$ \\
\hline Aeromonas caviae MEI & 20 & 7 & 50 & $3-4$ & $6.5-8$ & 7.1 & Kubata et al. 1992 \\
\hline $\begin{array}{c}\text { Bacillus } \\
\text { amyloliquefaciens }\end{array}$ & 18.5 & $\begin{array}{c}6.8- \\
7\end{array}$ & 80 & 9 & 50 & 10.1 & $\begin{array}{c}\text { Breccia et al. } \\
1998\end{array}$ \\
\hline $\begin{array}{l}\text { Bacillus circulans WL- } \\
12\end{array}$ & 85 & $\begin{array}{c}5.5- \\
7\end{array}$ & --- & --- & --- & 4.5 & $\begin{array}{c}\text { Esteban et al. } \\
1982\end{array}$ \\
\hline $\begin{array}{c}\text { Bacillus sp. Strain SPS- } \\
0\end{array}$ & 99 & 6 & 75 & --- & 70 & --- & $\begin{array}{c}\text { Esteban et al. } \\
1982\end{array}$ \\
\hline $\begin{array}{c}\text { Bacillus sp. } \\
\text { W1JCM2888 }\end{array}$ & 21.5 & 6 & 65 & $\begin{array}{c}4.5- \\
10\end{array}$ & --- & 8.5 & $\begin{array}{c}\text { Akiba \& } \\
\text { Horikoshi } 1988\end{array}$ \\
\hline Bacillus sp. strain 41-1 & 36 & 9 & 50 & --- & --- & 5.3 & $\begin{array}{c}\text { Akiba \& } \\
\text { Horikoshi } 1988\end{array}$ \\
\hline Bacillus sp. strain K-1 & 23 & 5.5 & 60 & 12 & 50 & --- & $\begin{array}{l}\text { Ratanakhanokchai } \\
\text { et al. } 1999\end{array}$ \\
\hline Streptomyces T-7 & 20.6 & $\begin{array}{l}4.5- \\
5.5\end{array}$ & 60 & $\begin{array}{l}5 \\
5.5-\end{array}$ & 37 & 7.8 & Keskar et al. 1989 \\
\hline Streptomyces sp. & $\begin{array}{l}50 \\
25 \\
25\end{array}$ & $\begin{array}{l}5.5- \\
6 \\
5-6 \\
5-6\end{array}$ & $\begin{array}{l}60-65 \\
60-65 \\
60-65\end{array}$ & $\begin{array}{c}6 \\
5.5- \\
6 \\
5.5- \\
6\end{array}$ & $\begin{array}{l}55 \\
55 \\
55\end{array}$ & $\begin{array}{l}7.1 \\
10 \\
10\end{array}$ & $\begin{array}{c}\text { Nakanishi et al. } \\
1992\end{array}$ \\
\hline $\begin{array}{c}\text { Acidobacterium } \\
\text { capsulatum }\end{array}$ & 41 & 5 & 65 & --- & --- & 7.3 & $\begin{array}{l}\text { Inagaki et al. } \\
\quad 1998\end{array}$ \\
\hline $\begin{array}{l}\text { Bacillus circulans WL- } \\
\qquad 12\end{array}$ & 15 & $\begin{array}{c}5.5- \\
7\end{array}$ & --- & --- & --- & 9.1 & Joshi et al. 2008 \\
\hline $\begin{array}{c}\text { Bacillus } \\
\text { stearothermophilus T-6 }\end{array}$ & 43 & 6.5 & 55 & --- & --- & 7.9 & Khasin et al. 1993 \\
\hline $\begin{array}{l}\text { Bacillus polymyxa } \\
\text { CECT } 153\end{array}$ & 61 & 6.5 & 50 & --- & --- & 4.7 & $\begin{array}{l}\text { Morales et al. } \\
1995\end{array}$ \\
\hline Bacillus sp. NG-27 & --- & 7 & 70 & --- & --- & --- & Gupta et al. 1992 \\
\hline Cellulomonas fimi & $14-150$ & $\begin{array}{l}5- \\
6.5\end{array}$ & $40-45$ & --- & --- & $4.5-8.5$ & Khanna 1993 \\
\hline $\begin{array}{c}\text { Staphylococcus sp. SG- } \\
13\end{array}$ & 60 & $\begin{array}{l}7.5 \\
9.2\end{array}$ & 50 & --- & --- & --- & Gupta 2000 \\
\hline $\begin{array}{l}\text { Thermoanaerobacterium } \\
s p . \text { JW/SL-YS485 }\end{array}$ & $24-180$ & 6.2 & 80 & --- & --- & 4.3 & Shao et al. 1995 \\
\hline \begin{tabular}{l}
\multicolumn{1}{c}{ Yeast } \\
Aureobasidium \\
pullulans Y-2311-1
\end{tabular} & 25 & 4.4 & 54 & --- & --- & 9.4 & Li et al. 1993 \\
\hline Cryptococcus albidus & 48 & 5 & 25 & --- & --- & --- & $\begin{array}{c}\text { Morosoli et al. } \\
1986\end{array}$ \\
\hline $\begin{array}{l}\text { Trichosporon cutaneum } \\
\text { SL409 }\end{array}$ & --- & 6.5 & 50 & --- & --- & --- & Liu et al. 1998 \\
\hline Streptomyces sp B-12-2 & 23.8 & $6-7$ & $55-60$ & $-{ }_{-}^{--}$ & --- & 4.8 & Elegir et al. 1995 \\
\hline $\begin{array}{l}\text { Streptomyces } \\
\text { thermoviolaceus OPC- } \\
520\end{array}$ & 33 & 7 & $50-70$ & --- & --- & 4.2 & $\begin{array}{l}\text { Tsujibo et al. } \\
1992\end{array}$ \\
\hline $\begin{array}{l}\text { Streptomyces } \\
\text { viridisporus } T 7 A\end{array}$ & 59 & $7-8$ & $55-70$ & --- & --- & 10.2 & $\begin{array}{c}\text { Magnuson \& } \\
\text { Crawford, } 1997\end{array}$ \\
\hline $\begin{array}{l}\text { Streptomyces sp. } Q G- \\
11-3\end{array}$ & --- & 8.6 & 50 & --- & --- & --- & Beg et al. 2000 \\
\hline $\begin{array}{l}\text { Thermomonospora } \\
\text { curvata }\end{array}$ & 15 & 6.8 & 75 & --- & --- & 4.2 & $\begin{array}{c}\text { Stuzenberger \& } \\
\text { Bodine, } 2008\end{array}$ \\
\hline
\end{tabular}




\section{Composition and amino acid sequence of xylanases}

The amino acid composition of xylanases reported in various sources indicate that aspartic acid, glutamic acid, glycine, serine and threonine make up the largest percentage of these proteins, and the amino acids responsible for the catalysis of xylan are two glutamic acids that behave as acid and base, which can be found in the active site of these enzymes. Data from amino acid sequences, X-ray crystallographic data, molecular data and available computational design of xylanases provide information that elucidates the structure and function of these enzymes, allowing to realize the improvement in stability at high temperatures and alkaline pH (Biely et al. 1997, Kulkarni et al. 1999, Sharma \& Kumar 2013). Paice et al. (1986) mentioned that the xylanases of Bacillus subtilis and Bacillus pumilus were sequenced completely, finding 185 and 201 amino acid residues in each chain, respectively. Furthermore partial amino acid sequencing of the fungus Cryptococcus albidus was performed, finding 72 amino acid residues from the N-terminal end (Morosoli et al. 1986, Sharma \& Kumar 2013).

\section{Carbohydrate binding}

Xylanases have the ability to bind carbohydrates other than xylan, which has been observed in structures of endo-xylanases from glycoside hydrolase families 10 and 11. Family 10 have a cellulose binding domain. Family 11 show a $\beta$ jelly roll structure with a very small molecular weight, so they can penetrate the hemicellulose. The carbohydrate-binding modules have great potential for applications in lignocellulosic residues. For example, xylanase of Cellulomonas fimi has two carbohydrate binding sites, one for xylan and the other for cellulose; spectroscopy determined that such sites are formed by two exposed tryptophan residues on the surface, Trp-570 and Trp-602, having a perpendicular orientation to each other, which demonstrates that these amino acids are essential for ligand binding. Changing the Arg-573 with glycine alters the binding module for the polysaccharides cellulose and xylan (Bolam et al. 2001, Gullfot et al. 2010, Juturu \& Wu 2012, Sharma \& Kumar 2013).

\section{Activators and inhibitors of xylanases}

Xylanase activity is affected by the presence of metal ions and some compounds; $\mathrm{Hg}^{+2}$, $\mathrm{Fe}^{+2}, \mathrm{Co}^{+2}, \mathrm{Mn}^{+2}, \mathrm{Cu}^{+2}$ and EDTA act as inhibitors, while $\mathrm{Ca}^{+2}$ and $\mathrm{Mg}^{+2}$ act as activators. In one study the effect of different metal ions on the activities of xylanase and endo-xylanase of Aspergillus awamori was evaluated when the enzymes were incubated for $1 \mathrm{~h}$ at $40{ }^{\circ} \mathrm{C}$ and the residual activity was determined. Heavy metals such as $\mathrm{Ag}^{+2}$ and $\mathrm{Hg}^{+2}$ as well as EDTA inhibited enzymatic activity by $80-90 \%$. Divalent elements such as $\mathrm{Ca}^{+2}$ and $\mathrm{Mg}^{+2}$ increased activity by $10-$ $15 \%$, because these ions stabilise the enzyme-substrate complex, increasing enzyme activity. Conversely, EDTA is a chelating agent that removes ions, inhibiting enzyme activity (Carmona et al. 2005, Yinan et al. 2008, Zhou et al. 2009, Juturu \&Wu, 2012, Álvarez-Cervantes et al. 2013). Furthermore, during fungal infection of plants, it has been found that chitinase acts as an inhibitor of the main enzymes that degrade the cell wall such as proteases and xylanases. Chitinase enzymes act as defense molecules to protect the plant from attack by pathogens or causing damage to pathogens. Recently, a chitinase was isolated from coffee. During germination of spores of Asian soybean rust (Phakopsora pachyrhizi) the chitinase decreased xylanase activity by $45 \%$. This chitinase inhibited xylanases of Acrophialophora nainiana by $60 \%$. In general, it has been suggested that chitinase proteins produced by plants are a defense mechanism acting as inhibitors against pathogens (Durand et al. 2005, Tokunaga \& Esaka 2007, Biely et al. 2008, Vasconcelos et al. 2011, Sharma \& Kumar, 2013).

\section{Glycosylation in xylanases}

Glycosylation is one of the most important cellular processes after protein translation. This phenomenon is common among eukaryotic xylanases, however, glycoproteins with xylanolytic activity of prokaryotes have been found, as in the case of Clostridium stercorarium, Streptomyces sp. and Bacillus sp. Studies to determine the glycosylation of these proteins have been mainly 
through their crystal structures. In general, carbohydrates are covalently attached to proteins. It has been proposed that glycosylation is associated with proteolysis contributing to multiple forms of xylanases (Berenger et al. 1985, Marui et al. 1985, Merivuori et al. 1985, Wong et al. 1988, Dey et al. 1992).

\section{Xylanase gene regulation}

Most xylanases produced by microorganisms are not constitutively expressed. Xylan, being a heteropolysaccharide of high molecular weight cannot enter the cell matrix so there is a basal level of production of xylanases acting on the substrate and xylose, xylobiose, xylotriose and other xylooligosaccharides are released, with low molecular weights which can easily go into the microbial cells. These low molecular weight sugars act as a carbon source and provide energy for growth and cell functions. These hydrolysis products also stimulate or induce the production of xylanases by different methods (Wang et al. 1992, Subramaniyan \& Prema 2002). Glucose present in the medium, acts as a carbon source and may also participate in repression of the synthesis of catabolic enzymes at the transcriptional level (Thomson 1993, Zhao et al. 1997, Subramaniyan \& Prema 2002) (Fig. 4). Catabolic repression by glucose is a common phenomenon in the biosynthesis of xylanases. A study in the yeast Cryptococcus albidus in the presence of xylan, showed that cAMP is involved in the production of xylanase as an inducer. However, cAMP did not have an effect on repression caused by D-xylose, so it was suggested that there is a nucleotide sequence $15 \mathrm{bp}$ upstream of the gene of L-xylanase, which can be a regulatory sequence of the CAMP and that the catabolic repression of xylanase appears to be controlled on two levels; directly by the repression of gene transcription and indirectly by suppressing a transcriptional activator. This regulation pattern was observed in A. niger and A. nidulans (Kulkarni et al. 1999).

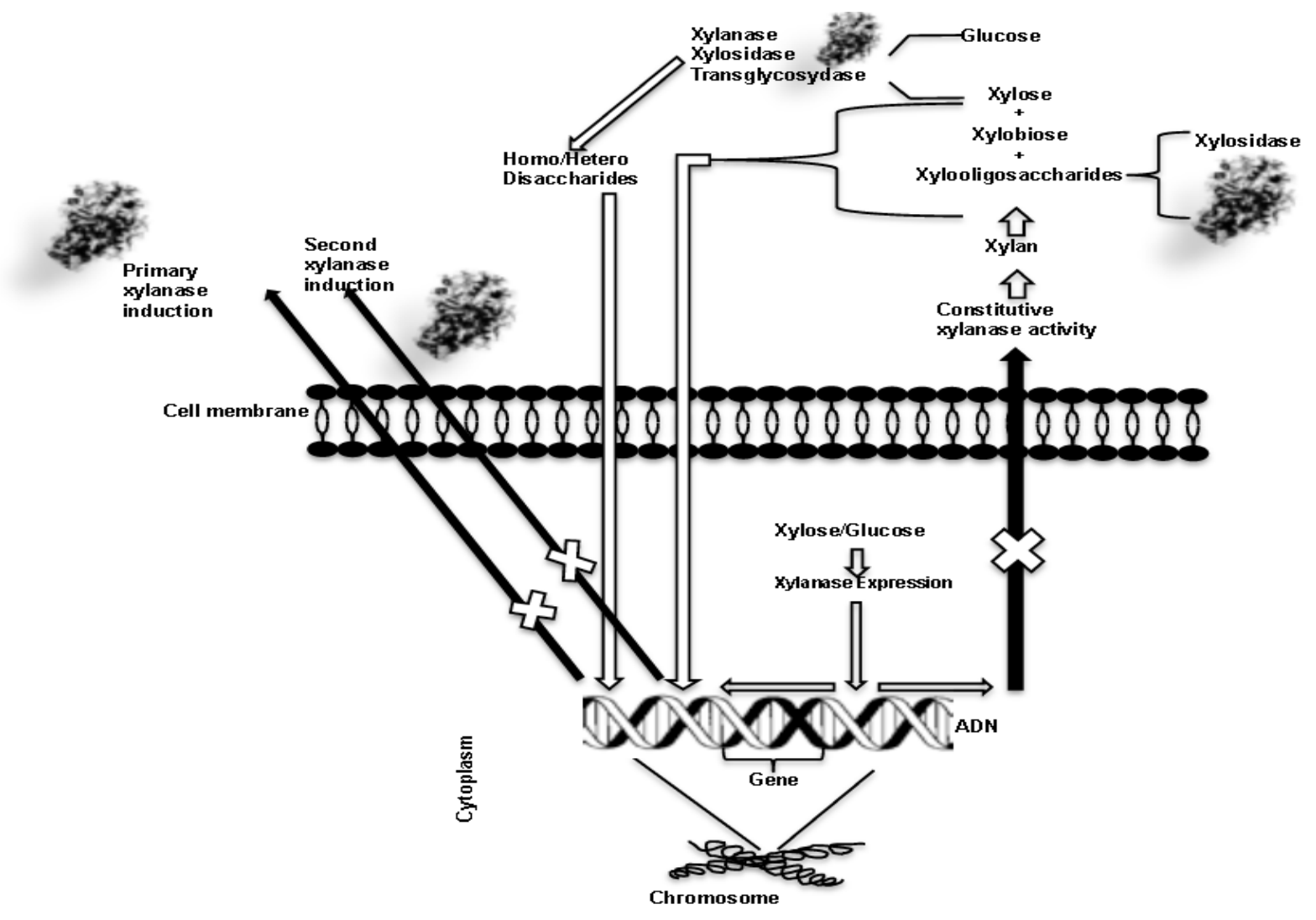

Fig. 4 - Hypothetical model for the regulation of xylanases in bacteria. Xylose is a monomer that can easily be transported across the cell membrane to induce the synthesis of xylanases. Constitutive action of xylanases produce xylooligosaccharides and xylotriose which are transported to the cell membrane and induces the synthesis of enzymes. 


\section{Cloning and expression of xylanase}

In order to meet industry requirements, xylanases must have specific properties, such as stability over a wide range of $\mathrm{pH}$ and temperature, high specific activity and strong resistance to metal cations and chemicals. However, most of the reported xylanases do not possess all the characteristics required by industry. Native enzymes are not sufficient to meet demand due to low yield. Therefore, molecular studies have been implemented to improve the characteristics required. Heterologous expression is an important tool in the production of xylanases at an industrial level. Protein engineering enabled by recombinant DNA technology has improved specific characteristics of existing xylanases. Currently, homologous or heterologous expression of several genes encoding xylanases is performed, in bacteria, yeast and fungi, in the search for recombinant xylanases that exhibit better properties than native enzymes (Kulkarni et al. 1999, Juturu \& Wu 2012, Verma \& Satyanarayana 2012, Motta et al. 2013, Sharma \& Kumar 2013).

Escherichia coli is a bacterium well known for its easy handling, its growth conditions are inexpensive, simple techniques are required for transformation and high levels of product accumulate in the cytoplasm of the cell. This organism has become the most commonly used expression host. However, and not all genes are readily expressed in Escherichia coli and it is not capable of functional expression of many xylanases. This problem can be caused by repetitive occurrence of codons and the lack of specific posttranslational modifications such as disulfide bond formation and glycosylation. Therefore, species such as Lactobacillus spp. and Bacillus subtilis are attractive hosts for the production of heterologous proteins with higher levels of expression than in Escherichia coli. In addition they present an interest in industry and research, due to the fact they are not toxic and are generally recognized as safe (GRAS) (Bron et al. 1998, Stewart et al. 1998, Kulkarni et al. 1999, Juturu \&Wu 2012)

The expression of heterologous proteins in yeast systems is very attractive, as these organisms provide additional benefits over bacterial expression systems, such as post-translational modifications, and they have the ability to increase cell density and secrete protein into the fermentation medium. Saccharomyces cerevisiae produces large amounts of xylanases in the culture medium, this yeast is already established as an industrial microorganism that can produce xylanases at low cost. Pichia pastoris can also be used as a host for the production of these enzymes due to the high expression using their own promoters (Ahmed et al. 2009, Juturu \&Wu 2012, Motta et al. 2013).

Filamentous fungi are producers of xylanases, and have been used as models of heterologous and homologous gene expressions, achieving high yields of protein production with their own promoters. Filamentous fungi have already been improved for protein secretion, as is the case for the expression of xylanase. A xylanase gene from Penicillium griseofulvum was successfully expressed in Aspergillus oryzae (Nevalainen et al. 2005, Juturu \& Wu 2012, Motta et al. 2013).

\section{Industrial applications}

Microbial xylanases currently have an important biotechnological potential for application in a diverse range of industries, called clean and sustainable technologies. Paper mills, textiles, agricultural and food industries have used xylanases in their processes. In 1979, the United States issued a patent for the production of xylanase and its use in feed for dairy cattle. Some important applications are: bioconversion of agroindustrial waste, juice clarification and improvement in the consistency of beer, digestibility of raw materials for animal feed, biobleaching of pulp paper, bioethanol and xylooligosaccharide production. Since then the use of such enzymes has increased significantly, covering a wide range of industrial sectors. Xylanases currently represent $20 \%$ of the global market for industrial enzymes (Polizeli et al. 2005, Loera-Corral \& Villaseñor-Ortega 2006, Dhiman et al. 2008, Michelin et al. 2010, Nair et al. 2010, Sharma \& Kumar 2013).

\section{Pharmaceutical and food industries}

Xylanases, with pectinases, amylases and cellulases can be used for the clarification of juices, they increase the performance of and enhance the maceration process as well as reduce the 
degree of viscosity. Xylanases may improve the extraction of coffee, vegetable oils and starch. Xylose resulting from hydrolysis of xylan can be converted to xylitol, a sweetener that has applications in the pharmaceutical and food industries. In the baking industry xylanase can improve the quality of bread, by increasing volume. These enzymes can also be applied in the preparation of animal feed to improve the nutritional properties of agricultural silage and grain. It also has been applied in the poultry diet improving the weight gain and feed conversion. The xylanase of the fungus Trichoderma longibrachiatum, when applied in the diet for broilers based on rye, reduced intestinal viscosity and improved weight gain and efficiency of feed conversion. Xylanases can also be used in cereals as a pretreatment for substrates rich in arabinoxylan. Arabinoxylans are soluble in water and thus increase the viscosity of the solution. This problem can occur in brewing, however, the xylanases improve the extraction of fermentable sugars for processing by reducing the viscosity and improving the filterability of the fluid. Furthermore, the xylooligosaccharides released by xylanases can be used in pharmaceutical, agricultural and food products, as prebiotics (Dhiman et al. 2008, Harris \& Ramalingam 2010, Lafond et al. 2011, Motta et al. 2013, Sharma \& Kumar 2013).

\section{Bioconversion of lignocellulose}

Today, second generation biofuels are the main products of the bioconversion of lignocellulosic materials. Ethanol is the most important renewable fuel in terms of volume and market value. The first generation of this fuel is from sugar and starch, and the second generation began to be tested in pilot plants, is beneficial as it does not compete with food production and is friendly with the environment. Xylanases, in conjunction with other hydrolytic enzymes can be used for producing fuels from lignocellulosic biomass. However, enzymatic hydrolysis presents a significant cost in the conversion of lignocellulosic feedstocks for the production of biofuel. The first step is the delignification of plant fibers to release cellulose and hemicellulose from their complex with lignin. The second step is a depolymerization of the chains of carbohydrates to produce free sugars followed by fermentation of pentoses and hexoses by microorganisms to produce ethanol (Olsson et al. 1996, Lee et al. 1997, Taherzaden \& Karimi 2007, Viikari et al. 2012, Dhiman et al. 2008, Michelin et al. 2010, Nair et al. 2010, Motta et al. 2013).

\section{Xylanase use in paper biobleaching}

In recent years, the use of enzymes in the paper pulp biobleaching is very important. Xylanases hydrolyze xylan and facilitates the release of lignin from paper pulp, which reduces the use of chlorine as a bleaching agent. This process using microbial enzymes is called biobleaching. One of the most important features of the xylanase extract is that it must be free from cellulose activity for its use in the biobleaching of paper (Viikari et al. 1994, Beg et al. 2001, Bajpai 2004, Sigoillot et al. 2005, Collins et al. 2005, Arzola et al. 2006, Loera-Corral \& Villaseñor-Ortega 2006, Dhiman et al. 2008, Michelin et al. 2010, Nair et al. 2010, Motta et al. 2013, Sharma \& Kumar 2013).

\section{References}

Ahmed S, Riaz S, Jamil A. 2009 - Molecular cloning of fungal xylanases: an overview. Applied Microbiology and Biotechnology 84, 19-35.

Akiba T, Horikoshi K. 1988 - Xylanases of alkalophilic thermophilic Bacillus. Methods in Enzymology 160, 655-659.

Álvarez-Cervantes J, Hernández-Domínguez EM, Arana-Cuenca A, Díaz-Godínez G, MercadoFlores Y. 2013 - Purification and characterization of xylanase SRXL1 from Sporisorium reilianum grown in submerged and solid-state fermentation. BioResources 8, 5309-5318.

Anthony T, Raj KC, Rajendran A, Gunasekaran P. 2003 - High molecular weight cellulase-free xylanase from alkali-tolerant Aspergillus fumigatus AR1. Enzyme and Microbial Technology 32, 647-654. 
Aro N, Pakula T, Pentitla M. 2005 - Transcriptional regulation of plant cell degradation by filamentous fungi. FEMS Microbiology Reviews 29, 719-739.

Arzola KG, Polvillo O, Arias ME, Perestelo F, Carnicero A, González-Vila FJ, Falcón MA. 2006 Early attack and subsequent changes produced in an industrial lignin by a fungal laccase and a laccase-mediator system: an analytical approach. Applied Microbiology and Biotechnology 73, 141-150.

Bajpai P. 2004 - Biological bleaching of chemical pulps. Critical Reviews in Biotechnology 24, 158.

Bayer EA, Belaich JP, Shoham Y, Lamed R. 2004 - The cellulosomes: multienzyme machines for degradation of plant cell wall polysaccharides. Annual Review Microbiology 58, 521-554.

Beg QK, Bhushan B, Kapoor M, Hoondal GS. 2000 - Enhanced production of a thermostable xylanase from Streptomyces sp. QG-11-3 and its application in biobleaching of eucalyptus kraft pulp. Enzyme and Microbial Technology 27, 459-466.

Beg QK, Kapoor M, Mahajan L, Hoondal GS. 2001 - Microbial xylanases and their industrial applications: a review. Applied Microbiology and Biotechnology 56, 326-338.

Belancic A, Scarpa J, Peirano A, Diaz R, Steiner J, Eyzayuirre J. 1995 - Penicillium purpurogenum produces several xylanases: purification and properties of two of the enzymes. Journal Biotechnology 41, 71-79.

Beliën T, Van Campenhout S, Van Acker M, Volckaert G. 2005 - Cloning and characterization of two endoxylanases from the cereal phytopathogen Fusarium graminearum and their inhibition profile against endoxylanase inhibitors from wheat. Biochemical and Biophysical Research Communications 327, 407-414.

Berenger J, Frixon C, Creuzet N, Bigliardi J. 1985 - Production, purification and properties of thermostable xylanase from Clostridium stercorarium. Canadian Journal of Microbiology 31, 635-643.

Biely P, Kluepfel D, Morosoli R, Shareck F. 1993 - Mode of action of three endo- $\beta$-1,4-xylanases of Streptomyces lividans. Biochimica et Biophysica Acta (BBA) - Protein Structure and Molecular Enzymology 1162, 246-254.

Biely P, Leathers TD, Cziszarova M, Vrsanska M, Cotta M A. 2008 - Endo- $\beta-1,4$-xylanase inhibitors in leaves and roots of germinated maize. Journal of Cereal Science 48, 27-32.

Biely P, Vrsanska M, Tenkanen M, Kluepfel D. 1997 - Endo- $\beta$-1,4-xylanase families: differences in catalytic properties. Journal of Biotechnology 57, 151-166.

Bolam DN, Xie H, White P, Simpson PJ, Hancock SM, Williamson M P, Gilbert HJ. 2001 Evidence for synergy between family $2 \mathrm{~b}$ carbohydrate binding modules in Cellulomonas fimi xylanase 11A. Biochemistry 40, 2468-2477.

Braun EJ, Rodrigues CA. 1993 - Purification and properties of an endoxylanase from a corn stalk rot strain of Erwinia chrysanthemi. Phytopathology 83, 332-338.

Breccia JD, Sineriz F, Baigori MD, Castro GR, Hatti-Kaul R. 1998 - Purification and characterization of a thermostable xylanase from Bacillus amyloliquefaciens. Enzyme Microbial Technology 22, 42-49.

Bron S, Bolhuis A, Tjalsma H, Holsappel S, Venema G, van Dijl J. 1998 - Protein secretion and possible roles for multiple signal peptidases for precursor processing in bacilli. Journal of Biotechnology 64, 3-13.

Cano À, Palet C. 2007 - Xylooligosaccharide recovery from agricultural biomass waste treatment with enzymatic polymeric membranes and characterization of products with MALDI-TOFMS. Journal of membrane science 291, 96-105.

Carmona EC, Fialho MB, Buchgnani ÉB, Coelho GD, Brocheto-Braga MR, Jorge JA. 2005 Production, purification and characterization of a minor form of xylanase from Aspergillus versicolor. Process Biochemistry 40, 359-364.

Cesar T, Mrša V. 1996 - Purification and properties of the xylanase produced by Thermomyces lanuginosus. Enzyme and Microbial Technology 19, 289-296.

Chantasingh D, Pootanakit K, Champreda V, Kanokratana P, Eurwilaichitr L. 2006 - Cloning, 
expression, and characterization of a xylanase 10 from Aspergillus terreus (BCC129) in Pichia pastoris. Protein Expression and Purification 46, 143-149.

Chavez R, Schachter K, Navarro C, Peirano A, Aguirre C, Bull P, Eyzaguirre J. 2002 - Differences in expression of two endoxylanase genes (xynA and xynB) from Penicillium purpurogenum. Gene 293,161-168.

Chen C, Chen JL, Lin TY. 1997 - Purification and characterization of a xylanase from Trichoderma longibrachiatam for xylooligosaccharide production. Enzyme Microbial Technology 21(2), 91-96.

Cho SG, Choi YJ. 1999 - Catabolite repression of the xylanase gene (xynA) expression in Bacillus stearothermophilus no. 236 and B. subtilis. Bioscience, Biotechnology, and Biochemistry 63, 2053-2058.

Christakopoulos P, Kekos D, Macris BJ, Claeyssens M, Bhat MK. 1996 - Purification and characterisation of a major xylanase with cellulase and transferase activities from Fusarium oxysporum. Carbohydrate Research 289, 91-104.

Collins T, Gerday C, Feller G. 2005 - Xylanases, xylanase families and extremophilic xylanases. FEMS Microbiology Reviews 29, 3-23.

Coughlan MP, Hazlewood GP. 1993 - $\beta-1$,4-D-xylan-degrading enzyme systems: biochemistry, molecular biology and applications. Biotechnology and Applied Biochemistry 17, 259-289.

Coughlan MP, Touhy MG, Filho EXF, Puls J, Claeyssens M, Vrsanska M, Hughes MM. 1993 Enzymological aspects of microbial hemicellulases with emphasis on fungal systems. In Hemicellulose and Hemicellulases. Coughlan MP and Hazlewood GP. Portlan Press, London. Pp: 53-84.

Coutinho P, Henrissat B. 1999 - Carbohydrate-active enzymes: an integrated database approach. In HJ Gilbert, G Davies, H Henrissat, B Svensson. Recent Advances in Carbohydrate Bioengineering. Cambridge: The Royal Society of Chemistry. Pp. 3-12.

Davies G, Henrissat B. 1995 - Structures and mechanisms of glycosyl hydrolases. Structure 3, 853-859.

De Vries RP, Kester HCM, Poulsen CH, Benen JAE, Visser J. 2000 - Synergy between enzymes from Aspergillus involved in the degradation of plant cell wall polysaccharides. Carbohydrates Research 327, 401-410.

De Vries RP, Visser J, De Graaff LH. 1999 - CreA modulates the XlnR-induced expression on xylose of Aspergillus niger genes involved in xylan degradation. Research in Microbiology $150,281-285$.

Dey D, Hinge J, Shendye A, Rao M. 1992 - Purification and properties of extracellular endoxylanases from an alkalophilic thermophilic Bacillus sp. Canadian Journal of Microbiology 38, 436-442.

Dhiman SS, Sharma J, Battan B. 2008 - Industrial applications and future prospects of microbial xylanases: a review. BioResources 3, 1377-1402.

Durand A, Hughes R, Roussel A, Flatman R, Henrissat B, Juge N. 2005 - Emergence of a subfamily of xylanase inhibitors within glycoside hydrolase family 18. FEBS Journal. 272, $1745-1755$.

Dusterhoft EM, Linssen VAJM, Voragen AGJ, Beldman G. 1997 - Purification characterization and properties of two xylanases from Humicola insolens. Enzyme Microbial Technology 20, 437-445.

Elegir G, Sykes M, Jeffries TW. 1995 - Differential and synergistic action of Streptomyces endoxylanases in prebleaching of kraft pulp. Enzyme Microbial Technology 117, 954-959.

Esteban R, Villanueva IR, Villa TG. 1982 - $\beta$-D-Xylanases of Bacillus circulans WL-12. Canadian Journal of Microbiology 28, 733-739.

Fernandez-Espinar MT, Pinaga F, de Graaff L, Visser J, Ramon D, Valles S. 1994 - Purification, characterization and regulation of the synthesis of an Aspergillus nidulans acidic xylanase. Applied Microbiology and Biotechnology 42, 555-562.

Fontes CM, Gilbert HJ, Hazlewood GP, Clarke JH, Prates JA, McKie VA, Nagy T, Fernandes TH, 
Ferreira LM. 2000 - A novel Cellvibrio mixtus family 10 xylanase that is both intracellular and expressed under non-inducing conditions. Microbiology 146, 1959-1967.

Goswami GK, Pathak RR. 2013 - Microbial xylanases and their biomedical applications: a review. International Journal of Basic \& Clinical Pharmacology 2, 237-246.

Gullfot F, Tan TC, von Schantz L, Nordberg Karlsson E, Ohlin M, Brumer H, Divne C. 2010 - The crystal structure of XG-34, an evolved xyloglucan-specific carbohydrate binding module. Proteins 78, 785-789.

Gupta N, Vohra RM, Hoondal GS. 1992 - A thermostable extracellular xylanase from alkalophilic Bacillus sp. NG-27. Biotechnology Letters 14, 1045-1046.

Gupta S, Bhushan B, Hoondal GS. 2000 - Isolation, purification and characterization of xylanase from Staphylococcus sp. SG13 and its application in bio bleaching of kraft pulp. Journal of Applied Microbiology 88, 325-334.

Harris AD, Ramalingam C. 2010 - Xylanases and its application in food industry: a review. Journal of Experimental Sciences 1, 1-11.

Henrissat B, Bairoch A. 1996 - Updating the sequence-based classification of glycosyl hydrolases. The Biochemical Journal 316, 695-696.

Henrissat B. 1991 - A classification of glycosyl hydrolases based on amino acid sequence similarities. The Biochemical Journal 280, 309-316.

Hernández-Domínguez EM, Rios-Latorre RA, Álvarez-Cervantes J, Loera-Corral O, RománGutiérrez AD, Díaz-Godínez G, Mercado-Flores Y. 2014 - Xylanases, Cellulases, and Acid Protease Produced by Stenocarpella maydis Grown in Solid-state and Submerged Fermentation. BioResources 9, 2341-2358.

Howard RL, Abotsi E, Jansen van Rensburg EL, Howard S. 2003 - Lignocellulose biotechnology: issues of bioconversion and enzyme production. African Journal of Biotechnology 2, 602619.

Inagaki K, Nakahira K, Mukai K, Tamura T, Tanaka H. 1998 - Gene cloning and characterization of an acidic xylanase from Acidobacterium capsulatum. Bioscience, biotechnology, and biochemistry 62, 1061-1067.

Jorge I, de la Rosa O, Navas-Cortés JA, Jiménez-Diaz RM, Tena M. 2005 - Extracellular xylanases from two pathogenic races of Fusarium oxysporum $f$. sp. ciceris: Enzyme production in culture and purification and characterization of a major isoform as an alkaline endo- $\beta-(1,4)-$ xylanase of low molecular weight. Antonie Van Leeuwenhoek 88, 49-59.

Joshi MD, Hedberg A, Mcintosh LP. 2008 - Complete measurement of the pKa values of the carboxyl and imidazole groups in Bacillus circulans xylanase. Protein science 6, 26672670.

Juturu V, Wu JC. 2012 - Microbial xylanases: Engineering, production and industrial applications. Biotechnology Advances 30, 1219-1227.

Keskar SS, Srinivasan MC, Deshpande VV. 1989 - Chemical modification of a xylanase from thermotolerant Streptomyces: evidence for essential tryptophan and cystein residues at the active site. Biochemical Journal 261, 49-55.

Khanna S. 1993 - Regulation, purification, and properties of xylanase from Cellulomonas fimi. Enzyme and Microbial Technology 15, 990-995.

Khasin A, Alchanati I, Shoham Y. 1993 - Purification and characterization of a thermostable xylanase from Bacillus stearothermophilus T-6. Applied and Environmental Microbiology $59,1725-1730$.

Kim JH, Kim JH, Kim SC, Nam SW. 2000 - Constitutive overexpression of the endoxylanase gene in Bacillus subtilis. Journal of Microbiology and Biotechnology 10, 551-553.

Kimura I, Sasahara H,Tajima S. 1995 - Purification and characterization of two xylanases and an arabinofuranosidase from Aspergillus sojae. Journal of Fermentation and Bioengineering 80, 334-339.

King BC, Waxman KD, Nenni NV, Walker LP, Bergstrom GC, Gibson DM. 2011 - Arsenal of plant cell wall degrading enzymes reflects host preference among plant pathogenic fungi. 
Biotechnology for Biofuels 4, 1-14.

Kolenová K, Vršanská M, Biely P. 2006 - Mode of action of endo- $\beta$-1, 4-xylanases of families 10 and 11 on acidic xylooligosaccharides. Journal of Biotechnology 121, 338-345.

Kormelink FJM, Leeuwen MGFSL, Wood TM, Voragen AGJ. 1993 - Purification and characterisation of three endo (1,4)- $\beta$-xylanases and one $\beta$-xylosidase from Aspergillus awamori. Journal of Biotechnology 27, 249-253.

Kubata KB, Horitsu H, Kawai K, Takamizawa K, Suzuki T. 1992 - Xylanase I of Aeromonas caviae ME-I isolated from the intestine of a herbivorous insect (Samia cynthia pryeri). Bioscience, Biotechnology and Biochemistry 56, 1463-1464.

Kulkarni N, Shendye RA, Rao M. 1999 - Molecular and biotechnological aspects of xylanases. FEMS Microbiology Reviews 23, 411-456.

Kumar J, Singh S, Singh OV. 2008 - Bioconversion of lignocellulose biomass: biochemical and molecular perspectives. Journal of Industrial Microbiology and Biotechnology 35, 377-391.

Lafond M, Tauzin A, Desseaux V, Bonnin E, Ajandouz EH, Giardina T. 2011 - GH10 xylanase D from Penicillium funiculosum: biochemical studies and xylooligosaccharide production. Microbial Cell Factories 10, 20.

Lee CC, Wong DWS, Robertson GH. 2005 - Cloning and characterization of the Xyn11A gene from Lentinula edodes. The Protein Journal 24, 21-26.

Lee J. 1997 - Biological conversion of lignocellulosic biomass to ethanol. Journal of Biotechnology 56, 1-24.

Leggio LL, Jenkins J, Harris GW, Pickersgill RW. 2000 - X ray crystallographic study of xylopentaose binding to Pseudomonas fluorescens xylanase A. Proteins: Structure, Function, and Bioinformatics 41, 362-373.

Li XL, Zhang ZQ, Dean JF, Eriksson KE, Ljungdahl LG. 1993 - Purification and characterization of a new xylanase (APX-II) from the fungus Aureobasidium pullulans Y-2311-1. Applied and Environmental Microbiology 59, 3212-3218.

Liu W, Zhu W, Lu Y, Kong J, Ma G. 1998 - Production, partial purification and characterization of xylanase from Trichosporon cutaneum SL409. Process Biochemistry 33, 331-336.

Loera Corral O, Villaseñor-Ortega F. 2006 - Xylanases In Advances in agricultural and food biotechnology. RG Guevara-González \& I. Torres-Pacheco. CAB Direct Pp. 305-322.

Magnuson TS, Crawford DL. 1997 - Purification and characterization of an alkaline xylanase from Streptomyces viridosporus T7A. Enzyme and microbial technology 21, 160-164.

Markwalder HU, Neukom H. 1976 - Diferulic acid as a possible crosslink in hemicelluloses from wheat germ. Phytochemistry 15, 836-837.

Marui M, Nakanishi K, Tsueneo Y. 1985 - Immunological properties and constituent amino acids of three xylanases produced inductively from Streptomyces sp. Agricultural and Biological Chemistry 49, 3409-3413.

Merivuori H, Sands JA, Montenecourt BS. 1985 - Effects of tunicamycin on secretion and enzymatic activites of cellulase from Trichoderma reesei. Applied Microbiology and Biotechnology 23, 60-66.

Michelin M, Peixoto-Nogueira SC, Betini JHA, da Silva TM, Jorge JA, Terenzi HF, Polizeli MLTM. 2010 - Production and properties of xylanases from Aspergillus terricola Marchal and Aspergillus ochraceus and their use in cellulose pulp bleaching. Bioprocess and Biosystems Engineering 33, 813-821.

Monti R, Cardillo L, Custodio MF, Goulard AJ, Sayama AH, Contiero J. 2003 - Production and purification of an endo-1,4- $\beta$-xylanase from Humicola grisea var thermoidea by electroelution. Brazilian Journal of Microbiology 34, 124-128.

Morales P, Madarro A, Flors A, Sendra J, Pérez-González J. 1995 - Purification and characterization of a xylanase and an arabinofuranosidase from Bacillus polymyxa. Enzyme and Microbial Technology 17, 424-429.

Morosoli R, Roy C, Yaguchi M. 1986 - Isolation and partial primary sequence of a xylanase from the yeast Cryptococcus albidus. Biochimica et Biophysica Acta (BBA)-Protein Structure 
and Molecular Enzymology 870, 473-478.

Motta FL, Andrade CCP, Santana MHA. 2013 - A review of xylanase production by the fermentation of xylan: classification, characterization and applications In Sustainable Degradation of Lignocellulosic Biomass-Techniques, Applications and Commercialization. AK. Chandel \& SS. da Silva. InTech.

Nair SG, Sindhu R, Shashidhar S. 2010 - Enzymatic bleaching of kraft pulp by xylanase from Aspergillus sydowii SBS 45. Indian Journal of Microbiology 50, 332-338.

Nakanishi K, Marui M, Yasui T. 1992 - Comparison of xylan and methyl $\beta$-xyloside-induced xylanases from Streptomyces sp. Journal of Fermentation and Bioengineering. 74, 392-394.

Nevalainen KMH, Te'o VSJ, Bergquist PL. 2005 - Heterologous protein expression in filamentous fungi. Trends in Biotechnology 23, 468-474.

Olsson L, Hahn-Hägerdal B. 1996 - Fermentation of lignocellulosic hydrolysates for ethanol production. Enzyme and Microbial Technology 18, 312-331.

Paice MG, Bourbonnais R, Desrochers M, Jurasek L, Yaguchi M. 1986 - A xylanase gene from Bacillus subtilis: nucleotide sequence and comparison with B. pumilus gene. Archives of Microbiology 144, 201-206.

Polizeli MLTM, Rizzatti ACS, Monti R, Terenzi HF, Jorge JA, Amorim DS. 2005 - Xylanases from fungi: properties and industrial applications. Applied Microbiology and Biotechnology 67, 577-591.

Ratanakhanokchai K, Kyu KL, Tanticharoen M. 1999 - Purification and properties of a xylanbinding endoxylanase from alkaliphilic Bacillus sp. strain K-1. Applied and Environmental Microbiology 65, 694-697.

Rye CS, Withers SG. 2000 - Glycosidase mechanisms. Current Opinion in Chemical Biology 4, 573-580.

Sabini E, Wilson KS, Danielsen S, Schülein M, Davies GJ. 2001 - Oligosaccharide binding to family 11 xylanases: both covalent intermediate and mutant product complexes display $(2,5)$ B conformations at the active centre. Acta Crystallographica. Section D, Biological Crystallography 57, 1344-1347.

Salles BC, Cunha RB, Fontes W, Sousa MV, Filho EXF. 2000 - Purification and characterization of a new xylanase from Acrophialophora nainiana. Journal Biotechnology 81(2-3), 199204.

Sapag A, Wouters, J, Lambert C, de loanes P, Eyzaguirre J, Depiereux. 2002 - The endoxylanases from family 11: computer analysis of protein sequences reveals important structural and phylogenetic relationships. Journal of Biotechnology 95, 109-131.

Schulze E. 1891 - Information regarding chemical composition of plant cell membrane. Deutsche Chemische Gesellschaft 24, 2277-2287.

Segura BG, Durand R, Fèvre M. 1998 - Multiplicity and expression of xylanases in the rumen fungus Neocallimastix frontalis. FEMS Microbiology Letters 164, 47-53.

Shao W, DeBlois S, Wiegel J. 1995 - A High-Molecular-Weight, Cell-Associated Xylanase Isolated from Exponentially Growing Thermoanaerobacterium sp. Strain JW/SL-YS485. Applied and Environmental Microbiology 61, 937-940.

Sharma M, Kumar A. 2013 - Xylanases: An overview. British Biotechnology Journal 3, 1-28.

Sigoillot C, Camarero S, Vidal T, Record E, Asther M, Pérez-Boada M, Martínez ÁT. 2005 Comparison of different fungal enzymes for bleaching high-quality paper pulps. Journal of Biotechnol 115, 333-343.

Stewart EJ, Åslund F, Beckwith J. 1998 - Disulfide bond formation in the Escherichia coli cytoplasm: an in vivo role reversal for the thioredoxins. EMBO Journal 17, 5543-5550.

Stülke J, Hillen W. 2000 - Regulation of carbon catabolism in bacillus species. Annual Review of Microbiology 54, 849-880.

Stutzenberger FJ, Bodine AB. 2008 - Xylanase production by Thermomonospora curvata. Journal of Applied Microbiology 72, 504-511.

Subramaniyan S, Prema P. 2002 - Biotechnology of microbial xylanases: enzymology, molecular 
biology, and application. Critical Reviews in Biotechnology 22, 33-64.

Sung WL, Luk CK, Chan B, Wakarchuk W, Yaguchi M, Campbell R, Willick G, Ishikawa K, Zahab DM. 1995 - Expression of Trichoderma reesei and Trichoderma viride xylanases in Escherichia coli. Biochemistry and Cell Biology 73, 253-259.

Sunna A, Antranikian G. 1997 - Xylanolytic enzymes from fungi and bacteria. Critical Reviews in Biotechnology 17, 39-67.

Taherzadeh MJ, Karimi K. 2007 - Enzyme-based hydrolysis processes for ethanol from lignocellulosic materials: a review. BioResources 2, 707-738.

Tan LUL, Wong KKY, Yu EKC, Saddler JN. 1985 - Purification and characterization of two DXylanases from Trichoderma harzianum. Enzyme and Microbial Technology 7, 425-430.

Tanaka H, Muguruma M, Ohta K. 2006 - Purification and properties of a family-10 xylanase from Aureobasidium pullulans ATCC 20524 and characterization of the encoding gene. Applied Microbiology and Biotechnology 70, 202-211.

Thomson JA. 1993 - Molecular biology of xylan degradation. FEMS Microbiology Review 104, 65-82.

Timell TE. 1967 - Recent progress in the chemistry of wood hemicelluloses. Wood Science and Technology 1, 45-70.

Tjalsma H, Antelmann H, Jongbloed JD, Braun PG, Darmon E, Dorenbos R, Dubois JY, Westers H, Zanen G, Quax WJ, Kuipers OP, Bron S, Hecker M, van Dijl JM. 2004 - Proteomics of Protein Secretion by Bacillus subtilis: Separating the "Secrets" of the Secretome. Microbiology and Molecular Biology Reviews 68, 207-233.

Tokunaga T, Esaka M. 2007 - Induction of a novel XIP-type xylanase inhibitor by external ascorbic acid treatment and differential expression of XIP-family genes in rice. Plant Cell Physiology 48, 700-714.

Tsujibo H, Miyamoto K, Kuda T, Minami K, Sakamoto T, Hasegawa T, Inamori Y. 1992 Purification, properties, and partial amino acid sequences of thermostable xylanases from Streptomyces thermoviolaceus OPC-520. Applied and Environmental Microbiology 58, 371-375.

Ujiie M, Roy C, Yaguchi M. 1991 - Low molecular weight xylanase from Trichoderma viride. Applied and Environmental Microbiology 57, 1860-1862.

Vadi RM, Strohfus BRH, West TP. 1996 - Characterisation of a xylanase from Aureobasidium pullulans. Microbios 85, 179-187.

Vafiadi C, Christakopoulos P, Topakas E. 2010 - Purification, characterization and mass spectrometric identification of two thermophilic xylanases from Sporotrichum thermophile. Process Biochemistry 45, 419-424.

Vasconcelos EAR, Santana CG, Godoy CV, Seixas CDS, Silva MS, Moreira LRS, Oliveira-Neto, OB, Price D, Fitches E, Filho EXF, Mehta A, Gatehouse JA, Grossi-De-Sa MF. 2011 - A new chitinase-like xylanase inhibitor protein (XIP) from coffee (Coffea arabica) affects Soybean Asian rust (Phakopsora pachyrhizi) spore germination. BMC Biotechnology $11 \mathrm{p}$. 14.

Velkova ZI, Gocheva VK, Kostov G, Atev A. 2007 - Optimization of nutritive media composition for hylanase production be Aspergillus awamori. Bulgarian Journal of Agricultural Science 13, 651-656.

Verma D, Satyanarayana T. 2012 - Molecular approaches for ameliorating microbial xylanases. Bioresource Technology 117, 360-367.

Viikari L, Kantelinen A, Sundquist J, Linko M. 1994 - Xylanases in bleaching: from an idea to the industry. FEMS Microbiology Reviews 13, 335-350.

Viikari L, Vehmaanperä J, Koivula A. 2012 - Lignocellulosic ethanol: From science to industry. Biomass and Bioenergy 46, 1-12.

Wang P, Ali S, Mason JC, Sims PFG, Broda P. 1992 - Xylanases from Streptomyces cyaneus, in Xylans and Xylanases. J. Visser, MA. Kusters-van Someran, AGJ. Voragen. Elsevier Science Publishers, Amsterdam BV, Pp. 225. 
Wang Y, Zhang H, He Y, Luo H, Yao B. 2007 - Characterization, gene cloning, and expression of a novel xylanase XYNB from Streptomyces olivaceoviridis A1. Aquaculture 267, 328-334.

Wong KKY, Tan LUL, Saddler JN. 1988 - Multiplicity of L-1,4-xylanase in microorganism: Functions and applications. Microbiological Reviews 52, 305-317.

Yang CH, Yang SF, Liu WH. 2007 - Production of xylooligosaccharides from xylans by extracellular xylanases from Thermobifida fusca. Journal of Agricultural and Food Chemistry 55, 3955-3959.

Yang R, Xu S, Wang Z, Yang W. 2005 - Aqueous extraction of corncob xylan and production of xylooligosaccharides. LWT-Food Science and Technology 38, 677-682.

Yinan Yang KS, Lifeng Ping, Jingmei Lul. 2008 - Cloning, sequencing and expression of a novel xylanase cDNA from a newly isolated Aspergillus awamori in Pichia pastoris. African Journal of Biotechnology 7, 4251-4259.

Yip VLY, Withers SG. 2004 - Nature's many mechanisms for the degradation of oligosaccharides. Organic and Biomolecular Chemistry 2, 2707-2713.

Zhang M, Jiang Z, Yang S, Hua C, Li L. 2010 - Cloning and expression of a Paecilomyces thermophila xylanase gene in $E$. coli and characterization of the recombinant enzyme. Bioresource Technology 101, 688-695.

Zhao Y, Chany II CJ, Sims PFG, Sinnott ML. 1997 - Definition of the substrate specificity of the 'sensing' xylanase of Streptomyces cyaneus using xylooligosaccharide and cellooligsaccharide glycosides of 3,4-dinitrophenol. Journal of Biotechnology 57, 181-190.

Zhou C, Yongtao W, Minchen Wu, Wu W, Dongfeng Li. 2009 - Heterologous expression of xylanase II from Aspergillus usamii in Pichia pastoris. Food Technology and Biotechnology 1, 90-95. 